
A Helpman-Melitz-Rubinstein Approach with Panel Data

\author{
Inmaculada Martínez-Zarzoso \\ Martina Vidovic \\ Anca M. Voicu
}

CESIFO WORKING PAPER NO. 4903

CATEgORY 8: TRADE POLICY

JULY 2014

An electronic version of the paper may be downloaded

- from the SSRN website:

- from the RePEc website:

- from the CESifo website:

wWw.SSRN.com

www.RePEc.org

www.CESifo-group.org/wp

\title{
CESifo
}




\title{
EU-Accession Effects on Sectoral Trade: A Helpman-Melitz-Rubinstein Approach with Panel Data
}

\begin{abstract}
This paper estimates the effects of the EU enlargements in the 2000s for trade in parts and components and trade in final goods separately. A gravity model is applied to disaggregated trade data over the period 1999-2009 for trade between EU and OECD countries. The estimation approach accounts for firm heterogeneity and selection bias in a panel-data framework. We find a positive and significant effect of the EU-accession on CEECs trade in intermediate and final goods. The main findings indicate that the effect of EU accession is higher on trade in intermediate goods than on trade in final goods.
\end{abstract}

JEL-Code: F100, F140.

Keywords: gravity equation, panel data, production networks, economic integration, trade flows.

\author{
Inmaculada Martínez-Zarzoso \\ Department of Economics \\ Georg-August Universitaet Goettingen \\ Platz der Goettinger Sieben 3 \\ Germany - Goettingen 37073 \\ martinei@eco.uji.es
}

\author{
Martina Vidovic \\ Department of Economics \\ Rollins College \\ 1000 Holt Avenue \\ USA - Winter Park, FL 32724 \\ mvidovic@rollins.edu
}

\author{
Anca M. Voicu \\ Department of Economics \\ Rollins College \\ 1000 Holt Avenue \\ USA - Winter Park, FL 32724 \\ avoicu@rollins.edu
}

The author acknowledges the support and collaboration of Project ECO2010-15863 financed by the Spanish Ministry of Science and Innovation. We also would like to thank the participants of the "Gravity Model” workshop held at CESifo for their helpful comments and suggestions, which have been incorporated to the paper. 


\section{EU-ACCESSION EFFECTS ON SECTORAL TRADE: A HELPMAN-MELITZ- RUBINSTEIN APPROACH WITH PANEL DATA}

\section{Introduction}

Free trade in most industrial products between the European Union (EU) and each individual Central Eastern European country (CEEC) was already established in 1994 with the Europe Agreements, and a deeper integration was achieved when eight and two CEECs gained full accession into the EU in 2004 and 2007, respectively. Full accession implied a reduction, and in some instances elimination, of the socalled "behind the border” barriers that are considered to be an important component of trade costs that goes beyond the traditional tariff barriers. In the last decade CEECs countries have increased their trade not only in final goods but also in intermediate products with former EU members. The splitting of the production process implies that products cross borders several times, production and in turn account for a rapid growth in trade. Furthermore, the gains from free trade may be amplified when production processes are reallocated to the most efficient locations in terms of costs and comparative advantage (Yi, 2003).

An important question that has been only partially answered in the related literature is to what extent the increase in trade is due to economic integration. By distinguishing between final and intermediate goods trade, this research is different to the work done by Antimiani and Constantini (2013) and Hornok (2010) who only estimated the effects of the 2004-enlargement on trade, but not of the 2007 enlargement, and not for part and components and using standard methods. The main novelty in this paper is that we differentiate between trade in part and components and final goods and estimate the effects of full accession for these two types of goods separately. A second innovation is 
the use of a methodology that allows us to incorporate firm heterogeneity and fixed costs of exporting into the modeling strategy. More specifically, the main research questions examined in this paper is whether the full accession of the (10+2) CEECs into the EU in 2004 and 2007 affects trade in intermediate and final goods between the CEECs and the OECD countries differently and whether the increase in exported final goods from the CEECs to the OECD countries can be explained in part by the increase in new intermediate products imported. We employ a theoretically justified gravity model based on Anderson and Van Wincoop (2003) and apply the estimation procedure developed by Helpman, Melitz and Rubinstein (2008) which exploits the frequency of zeros in bilateral trade data to assess the effects of trade barriers and accounts for firm heterogeneity and sample selection on the intensive margin. The model is estimated using highly disaggregated data for CEECs imports of parts and components from the OECD countries, and exports of final goods from the CEECs to the OECD countries over the period 1999 to 2009. Our analysis focuses on machinery industries ${ }^{1}$, since these sectors have been prominent in the development of production networks in Europe.

Our main results indicate that EU accession has increased trade volumes in both parts and components and final goods. Once we account for firm heterogeneity and selection bias in the model, the estimated effect of the CEECs' accession into the EU on final goods' trade is reduced and the effect on part and components is slightly higher in magnitude. This could indicate that part of this effect is due to trade diversification that may have emerged as a consequence of the decline in transport costs.

\footnotetext{
${ }^{1}$ Including general machinery, electrical machinery, transport equipment and precision machinery.
} 
The remainder of the paper is organized as follows. Section 2 provides a brief discussion of the related literature. Section 3 presents the gravity model and the empirical specifications to be estimated. Section 4 describes the data and presents the main results. The conclusions and policy implications are discussed in Section 5.

\section{Literature Review}

A number of studies have recently used the standard gravity trade model to examine the main factors responsible for the growth of fragmentation of trade (Athukorala and Yamashita, 2006; Kimura et al., 2007; Bergstrand and Egger, 2008; Baldwin and Taglioni, 2011; and Hayakawa and Yamashita, 2011). These studies usually distinguish between bilateral trade flows of final and intermediate goods, as well as FDI flows, and use highly disaggregate trade data to investigate whether the determinants of bilateral trade differ by type of goods., These studies find that the coefficients on the standard gravity variables such as economic size and distance all have the expected signs, but differ in magnitude. In particular the distance effect is ususallyfound to be higher for trade in intermediate goods. A number of authors focused on specific factors such as per capita income differences. Kimura et al. (2007) estimate a gravity model using trade in part and components for machinery industries for East Asia and Europe. They conclude that the trade in parts and components in Asia is the result of the existence of shared production networks which attempt to exploit the comparative advantage of each location, while in Europe the trade is dominated by horizontally differentiated goods which are not driven by per capita income differences between countries. The main drawback of this paper is that it estimates cross-section gravity 
models that do not include multilateral resistance terms and aggregates all trade flows into two single categories -final goods and intermediate goods-, hence incurring in aggregation bias and inconsistency of the estimates due to specification bias. Also using trade statistics, Navaretti, Haaland and Venables (2002) assessed the EU involvement into global production networks. They found that the shares of parts and components in total EU manufacturing (both imports and exports) have grown for trade with all geographic areas over the period 1990-1997. The highest shares were for trade within the EU and with North America. In particular within the EU, there was significant growth of networking with the CEECs following their gradual economic integration with Western Europe since 1989. According to the study, the shares of parts and components in total EU manufacturing by the Eastern European countries increased from $4.5 \%$ to $15.3 \%$ for exports and from $5.8 \%$ to $12.3 \%$ for imports between 1990 and 1997. The authors concluded that although high-income countries display a higher share of trade in parts and components with the EU than low-income countries, some of the less developed areas that are geographically close and integrated into the EU are increasing their involvement in global production networks.

Bergstrand and Egger (2008) contributed to this literature by developing a theoretical rational for estimating simultaneous gravity equations for bilateral trade in final goods, intermediate goods and FDI flows. In their empirical estimation, they find that growth in trade in intermediates explains roughly one-fifth of the increase in FDI relative to final goods trade. Baldwin and Taglioni (2011) also distinguish in their estimation of gravity models between trade in final goods and trade in intermediate goods and mainly focus on the role played by the income variables in the gravity equation for 
intermediate goods trade and find that GDP as a measure of economic mass works less well for bilateral trade flows characterized by relatively high shares of intermediates trade but this is only a problem in studies that do not include fixed effects.

Also using gravity equations, Hayakawa and Yamashita (2011) examine the effects of Free Trade Agreements (FTA) on trade in final and intermediate goods separately. Interestingly, their results indicate that FTAs have a positive and significant effect on trade in final goods in both, the short and the long run, that materialize in higher trade in the first six years following the agreement. In contrast, the FTA effect on trade in intermediate goods is only positive and significant in the long run and higher bilateral trade associated with the FTAs is first observed six years after the implementation of the agreements.

The usual approach in gravity studies is to focus only on country pairs with strictly positive trade flows. According to the gravity theory, trade is the result of mass attraction and resistance from geographical distance. However, in some cases the attraction may not be strong enough to facilitate trade and ignoring such cases will underestimate the impact of distance barrier on trade. According to the so-called newnew trade theories based on firm heterogeneity in productivity and fixed cost of exporting (Melitz, 2003), a reduction in trade costs will lead to an increase in trade in two margins: the number of traded varieties (extensive margin) and the average volume of trade (intensive margin). Thus, the standard gravity models do not properly account for the effect of trade costs arising from geographic distance and transport on bilateral trade. Helpman et al., (2008) developed a system of gravity equations to estimate the effects of trade barriers on the intensive (trade volume) and extensive (number of exporting firms) 
margins of trade by exploiting the frequency of zero trade flows between pairs of countries. The authors find that the majority of the growth of trade between 1970 and the mid 1990 was due to the intensive margin of trade. To avoid the bias, we estimate their proposed system of equations. We will follow a similar approach to Helpman et al., (2008) to account for both margins of trade.

A number of authors have measured international fragmentation of production by using foreign trade statistics to classify goods into parts and components and finished products (Ng and Yeats, 2001, 2003; Yeats, 2001; Kaminski and Ng, 2005; Athukorala, 2006; Kimura et al, 2007; Zeddies, 2010 and Hayakawa and Yamashita, 2011)². Most studies focus on a subset of products within the categories machinery and transport equipment and miscellaneous manufacture articles (SITC 7 and 8 respectively). Similar to more recent studies (Athukorala, 2006; Kimura et al, 2007 and Hayakawa and Yamashita, 2011), we use not only the product description of final products and components from the SITC 7 and 8 categories (Revision 3) to classify products into parts and components and final products but also the correspondence between the Broad Economic Classification (BEC) and the SITC classification. The latest SITC revision (Revision 3) has made the separation of final products and components more accurate than before.

\section{Model specification and estimation issues}

In line with Bergstrand and Egger (2008) and Baldwin and Taglioni (2011) we estimate a gravity model of trade, which is commonly widely accepted framework for modeling bilateral trade flows (Anderson, 1979; Bergstrand, 1985; Anderson and van

\footnotetext{
${ }^{2}$ The other two are the outward procession trade statistics that capture the production fragmentation by MNEs (see Baldone et al., 2001 and Egger and Egger, 2005) and input-output tables that estimate vertical specialization where independent firms act together as a network (see Hummels, Ishii and Yi, 2001).
} 
Wincoop, 2003; Helpman, Melitz, and Rubinstein, 2008). According to this model, trade between two countries is explained by their nominal incomes, by the distance between their economic centers, and by a number of trade impeding, e.g. being a landlocked country, and trade facilitating factors, e.g, trading partners belong to the same regional integration agreements, share a common language or a common border. We also include a measure of imports of intermediate goods in order to investigate the effect of production networks in a country's exports of final goods. Adding the time dimension, the gravity models of trade for the volume of imports of intermediate goods, $M I n t_{i j k t}$, and for the volume of exports of final goods $X_{i j k t}$ of product $k$ from country $i$ to country $j$ in period $t$ in current Euros are given as

$$
\begin{aligned}
& M I n t_{i j k t}=\alpha_{0} Y_{i t}^{\alpha_{1}} Y_{j t}^{{ }^{\alpha_{2}}} \operatorname{DIST}_{i j}^{\alpha_{3}} F_{i j t}^{\alpha_{4}} u_{i j k t} \\
& X_{i j k t}=\beta_{0} Y_{i t}^{\beta_{1}} Y_{j t}{ }^{\beta_{2}} \operatorname{DIST}_{i j}^{\beta_{3}} M I n t_{i j k, t-1}^{\beta 4} F_{i j t}^{\beta_{5}} u_{i j k t}
\end{aligned}
$$

where $Y_{i t}\left(Y_{j t}\right)$ indicate the GDPs of the reporter (partner) in period $t$, and $D I S T_{i j}$ is the geographical distance between the capitals (or economic centers) of countries $i$ and $j$. In the empirical application we use CEECs imports of parts and components from the OECD+CEEC countries and CEECs exports of final goods to the OECD+CEEC countries. MInt $t_{i j k, t-1}$ denotes the volume of imports of intermediate goods in the previous period ${ }^{3}, F_{i j t}$ denotes other factors that impede or facilitate trade (trade agreements, having a common language, a colonial relationship, or a common border). Finally, $u_{i j k t}$ is an idiosyncratic error term that is assumed to be well behaved.

\footnotetext{
${ }^{3}$ Imports enter with one lag to avoid reverse causality issues.
} 
Usually the model is estimated in log-linear form. Taking logarithms and adding time-and-industry dummies and per capita income differences, we specify the augmented versions of models (1) and (2), as

$$
\begin{aligned}
& \operatorname{LMInt}_{i j k t}=\alpha_{0}+\phi_{t k}+\alpha_{1} L Y_{i t}+\alpha_{2} L Y_{j t}+\alpha_{3} L D I S T_{i j}+ \\
& +\alpha_{4} E U_{i j t}+\alpha_{5} \text { CONTIG }_{i j}+\alpha_{6} \operatorname{LAND}_{i j}+\alpha_{7} \text { CEEs }_{i j t}+\alpha_{8} \operatorname{LABSYD}_{i j t}+\eta_{i j k t} \\
& L X_{i j k t}=\beta_{0}+\gamma_{t k}+\beta_{1} L Y_{i t}+\beta_{2} L Y_{j t}+\beta_{3} L D I S T_{i j}+\beta_{4} L M I n t_{i j k, t-1}+ \\
& +\beta_{5} E U_{i j t}+\beta_{6} \text { CONTIG }_{i j}+\beta_{7} \text { LAND }_{i j}+\beta_{8} \text { CEEs }_{i j t}+\beta_{9} \text { LABSYD }_{i j t}+v_{i j k t}
\end{aligned}
$$

where $L$ denotes variables in natural logarithms, CONTIG takes the value of 1 if the partner countries share a border, zero otherwise and LAND takes the value of 1 if one of the trading countries is landlocked, 2 if both countries are landlocked and zero otherwise and ABSYD denotes the log of the absolute difference between per capita incomes as a proxy for income differences between countries; CEEs takes the value of 1 after accession for new accession countries trade and EU takes the value of 1 after accession for old-EU members' trade with new members. The other explanatory variables are described above. $\phi_{t k}$ and $\gamma_{t k}$ are specific time-sector fixed effects that control for omitted variables common to each trade flow but which vary over time and across industries (SITC, 3-digits). Finally, $\eta_{i j k t}$ and $v_{i j k t}$ are idiosyncratic error terms that are assumed to be well behaved. Specifications (3) and (4) are estimating using a Mundlak approach, which consist on extending the model with the averages of the time variant variables to control for the remaining bilateral unobserved heterogeneity that is time invariant and could be correlated with the error term, as proposed by Mundlak (1978). In this way the model accounts for bilateral time-invariant heterogeneity that is correlated 
with the regressors and we are able to directly estimate the coefficient of the time invariant variables.

Next, trading-partner effects could also be specified as fixed effects that according to Baier and Bergstrand (2007) should control for the potential endogeneity of the formation of free trade agreements. In this case, the influence of the variables that are time invariant, namely distance, landlocked countries and contiguity, cannot be directly estimated and it is subsumed into the bilateral dummies. Moreover, since we have highly disaggregated trade data, we are able to incorporate the sectoral dimension to the fixed effects ( $\delta_{i j k}$ and $\kappa_{i j k}$ ) in specifications (5) and (6) below. We also model time-variant, multilateral price terms, as proposed by Baldwin and Taglioni (2006) and Baier and Bergstrand (2007) using country-and-time effects, which vary every three years. As stated by Baldwin and Taglioni (2006). This inclusion should eliminate the bias stemming from the incorrect specification or omission of the terms that Anderson and van Wincoop (2003) called multilateral trade resistance.

The specification that accounts for the potential endogeneity of the EU dummy and for the multilateral price terms in a panel data framework is given by

$$
\begin{aligned}
& \text { LMInt }_{i j k t}=\alpha_{0}+\delta_{i j k}+\alpha_{1} C E E s_{i j t}+\alpha_{2} E U_{i j t}+\alpha_{3} L^{2} A B S Y D_{i j t}+ \\
& \sum_{1}^{N Y} P_{i j}^{1-\delta}+\sum_{1}^{N Y} P_{j y}^{1-\delta}+\varepsilon_{i j k t} \\
& L X_{i j k t}=\beta_{0}+\kappa_{i j k}+\beta_{1} C E E s_{i j t}+\beta_{2} E U_{i j t}+\beta_{3} L A B S Y D_{i j t}+\beta_{2} L M I n t_{i j k, t-1} \\
& +\sum_{1}^{N Y} P_{i y}^{1-\delta}+\sum_{1}^{N Y} P_{j y}^{1-\delta}+\mu_{i j k t}
\end{aligned}
$$

where $P_{i y}^{1-\sigma}$ and $P_{j y}^{1-\sigma}$ are time-variant, multilateral (price) resistant terms that are proxied with country dummies that vary every 3 years, and $\varepsilon_{i j k t}$ and $\mu_{i j k t}$ denote the error terms 
that are assumed to be independent and identically distributed. The other variables are defined as in equations (3) and (4), above. Income variables cannot be estimated because they are collinear with the exporter-and-time and importer-and-time dummy variables.

Finally, to incorporate firm heterogeneity and selection into exporting we consider a specification based on Helpman et al. (2008) adapted to panel data. The authors develop a theory of international trade that predicts positive, as well as zero, trade flows across pairs of countries and accounts for firm heterogeneity while allowing the number of exporting firms to vary across destination countries. The model yields a generalized gravity equation which corrects for the self-selection of firms into export markets and their impact on trade volumes. The authors derive from this theory a twostage estimation procedure that decomposes the impact of trade resistance measures on trade volumes into intensive (trade volume per exporter) and extensive (number of trading firms) margins. The authors propose a system of equations consisting of a selection equation in the first stage and a trade-flow equation in the second. They show that the traditional estimates obtained from cross-section gravity models are biased and that the bias is primarily due to the omission of the extensive margin, rather than due to selection into trade partners. In line with Helpman et al. (2008), we also estimate the proposed system of equations, but extend the method to panel data. The first equation specifies a latent variable that is positive only if country $i$ imports parts and components or exports final goods to country $j$ (equations 7 and 9, respectively) and is estimated for each year separately. The second equation specifies the log of bilateral imports or exports from country $i$ to country $j$ as a function of integration variables, absolute differences in per capita income, multilateral resistance terms and a variable, $\omega_{i j k t}$, that is an increasing 
function of the fraction of country i's firms that export to or import from country $j$ (equations 8 and 10, respectively). The resulting equations are

$$
\begin{aligned}
& \rho_{i j k t}^{1}=P\left(M_{i n t_{i j k t}}\right)=\Phi\left(\vartheta_{0}+\vartheta_{1} L Y_{i t}+\vartheta_{2} L Y_{j t}+\vartheta_{3} L Y H_{i t}+\vartheta_{4} L Y H_{j t}+\vartheta_{5} L D I S T_{i j}+\right. \\
& \left.\vartheta_{6} C O N T I G_{i j}+\vartheta_{7} L A N D_{i j}+\vartheta_{8} C E E s_{i j t}+\vartheta_{9} E U_{i j t}\right) \\
& L M I n t_{i j k t}=\alpha_{i j k}+\omega_{i j k t}^{1}+\alpha_{1} C E E s_{i j t}+\alpha_{2} E U_{i j t}+\alpha_{3} L A B S Y D_{i j t}+\sum_{1}^{N Y} P_{i y}^{1-\delta}+\sum_{1}^{N Y} P_{j y}^{1-\delta}+\varepsilon_{i j t} \\
& \rho_{i j k t}^{2}=P\left(X_{i j k t}\right)=\Phi\left(\theta_{0}+\theta_{1} L Y_{i t}+\theta_{2} L Y_{j t}+\theta_{3} L Y H_{i t}+\theta_{4} L Y H_{j t}+\theta_{5} M I n t_{i j k, t-1}+\right. \\
& \left.\theta_{6}+L D I S T_{i j}+\theta_{7} C O N T I G_{i j}+\theta_{8} L A N D_{i j}+\theta_{9} C E E s_{i j t}+\theta_{10} E U_{i j t}\right) \\
& L X_{i j k t}=\beta_{i j k}+\omega_{i j k t}^{2}+\beta_{1} C E E s_{i j t}+\beta_{2} E U_{i j t}+\beta_{3} L A B S Y D_{i j t}+\beta_{4} M I n t_{i j k, t-1}+ \\
& +\sum_{1}^{N Y} P_{i y}^{1-\delta}+\sum_{1}^{N Y} P_{j y}^{1-\delta}+\mu_{i j t}
\end{aligned}
$$

where $\alpha_{i j k}$ and $\beta_{i j k}$, are industry-dyadic fixed effects to control for unobserved heterogeneity and $Y H_{i t}\left(Y H_{j t}\right)$ are reporter (partner) GDPs per capita in period $t$ and the rest of variables have been described above.

The variables $\omega^{1}{ }_{i j k t}$ and $\omega^{2}{ }_{i j k t}$ are inverse functions of firm productivity. The error terms in all equations are assumed to be normally distributed. Clearly, the error terms in equations (7) and (8) and error terms in equations (9) and (10) are correlated. Helpman et al. (2008) construct estimates of the $\omega^{\mathrm{m}}{ }_{\mathrm{ijkt}}$ using predicted components of equation (7) or equation (9). They propose a second stage non-linear estimation that corrects for both sample-selection bias and firm heterogeneity bias. They also decompose the bias and find that for a single cross-section correcting only for firm heterogeneity addresses almost all the biases in the standard gravity equation. However, in a panel data setting this could be different. 
They implement a simple linear correction for unobserved heterogeneity $\left(\omega_{i j k t}^{m}\right)$

proxied with a transformed variable $\left(\hat{z}_{i j k t}^{* m}\right)$ given by,

$$
\hat{Z}_{i j k t}^{* m}=\Phi^{-1}\left(\hat{\rho}_{i j k t}^{m}\right)
$$

where $Z_{i j k t}^{* m}=\frac{Z_{i j k t}^{m}}{\sigma_{i j k t}^{\eta}}$ and $\Phi$ are the cumulative distribution functions (cdf) of the unitnormal distribution. $\hat{\rho}_{i j k t}^{m}$ are the predicted probabilities of imports and exports $(m=1,2)$ between country $i$ and country $j$, using the estimates from the panel-probit from Equations (7) and (9). They propose to introduce this term as a polynomial of third order. We also decompose the bias and use the inverse Mills ratio as a proxy for sample selection, and the linear prediction of exports and imports down-weighted by their standard errors as proxies for firm heterogeneity, all obtained from equations (7) and (9). The exclusion variables that permit identification are the time invariant bilateral variables as well as the income per capita variables that are included in the selection equation but not in the second step equation. We estimate the above specified models for data on 6 CEECs' imports from and exports to 32 destinations (6 CEECs+ the OECD countries) during the period 1999 to 2009.

\section{Data, variables and estimation results}

\subsection{Data and variables}

The bilateral flows on external trade are from the European Commission's EUROSTAT database. Based on the SITC Revision 3, and using a detailed level of disaggregation (5 digit SITC), we identified parts and components and their corresponding final products within the machinery and transport equipment group 
(SITC 7) and miscellaneous manufacture articles group (SITC 8). Based on the literature on production networks, we identified 12 product categories: power generating (SITC 71) and specialized (SITC 72) machinery, metalworking (SITC 73) and general industrial (SITC 74) machinery, office machines (SITC 75), telecommunications and sound recording equipment (SITC 76), electrical goods (SITC 77), road vehicles (SITC 78), other transport equipment (SITC 79), furniture (SITC 82), measuring instruments (SITC 874) and photographic equipment, optical goods and watches (SITC 88). In order to select relevant parts and components, we first referred to the United Nations' Broad Economic Category (BEC) classification system. The BEC classification system groups traded goods according to their main end use and it is defined in terms of the SITC system. Among seven major categories, industrial supplies (BEC 2), capital goods (BEC 4), and transport equipment (BEC 5) include a subcategory for 'parts and components'. The corresponding subcategories are BEC 22, 42 and 53. We chose only the items under these subcategories that also correspond to the SITC 7 and SITC 8 categories that we study. The final list of parts and components includes 276 items, while the list of final goods consists of 514 items $^{4}$. Our identification of parts and components follows work by Athukorala (2006), Kimura et al. (2007) and Hayakawa and Yamashita (2011).

GDP data measured at current prices and expressed in millions of Euros are from the EUROSTAT's national accounts database, while data on population are from the OECD National Accounts Statistics. Information on country-pair specific variables such as distance between countries $i$ and $j$, whether they have the same colonial origin, share a

\footnotetext{
${ }^{4}$ The list of countries as well as parts and components are provided in Tables A1 and A2 in the Appendix.
} 
common border or share a common language are from the CEPII ${ }^{5}$. Additional covariates include controls for regional trading arrangement. Our sample consists of 32 countries (30 OECD members and Bulgaria and Romania) for which complete data were available over the period 1999 to 2009. Summary statistics of all the variables are shown in Table 1.

\section{Table 1. Summary statistics}

\subsection{Main results}

Table 2 reports the baseline estimation results for disaggregated exports and imports at 3-digit SITC level. The models in columns 1, 2 and 3 show the results for the imports of intermediate goods, export of final goods and exports of final goods with imported inputs as added explanatory variable, respectively. The model has been estimated using the pooled OLS with time-and-industry dummy variables and with the averages over time of income variables (specified in eqs. (3) and (4)). All models are estimated using robust standard errors clustered across panels (exporter-importerindustry). The interest in this specification is that we are able to estimate the effects of the time-invariant variables and compare them with previous estimates in the literature. As already reported by other authors, we find a positive and significant effect of EU accession for both types of trade, and similar to Hornok (2010) a stronger effect on intra CEECs trade after accession (CEES dummy). The estimated coefficients for other gravity variables show some important differences between trade in intermediate goods and trade in final goods. It is important to notice that the distance effect is significantly higher on trade on intermediates $(-1.6)$ than final goods $(-1.1)$, whereas the effect of sharing a

\footnotetext{
${ }^{5}$ CEPII stands for Centre d'Etudes Prospectives et d'Informations Internationales.
} 
border on trade is slightly higher for trade in intermediate goods than for final goods, also indicating the importance of proximity for production sharing.

\section{Table 2. Determinants of Imports of Intermediate goods and Exports of Final Goods by the CEECs - Linear Models}

Columns 4, 5 and 6 in Table 2 show the results for models that include countrypair-industry fixed effects and time-varying country dummies (Equations 5 and 6). We use the two-way fixed effect within-estimator with robust standard errors ${ }^{6}$. The coefficient on the EU dummy variable in column 4 indicates that imports of intermediates by CEECs following their accession into the EU have increased by about 122 percent $\left.\{\exp [0.80]-1)^{*} 100\right\}$ from old EU countries and by 135 percent from new members. In addition, the coefficient on the EU for final goods (column 5) is positive and statistically significant and indicates that a sizeable increase in exports is due to accession (exports of final goods are 188 percent higher than before accession for old-EU and 2.29 for new-EU members). The last column of Table 2 show the results of the gravity equation estimated for final goods augmented with imports of intermediate goods in the previous period. The effect of intermediate imports on exports of final goods is positive and significant and indicates that a 10 percent increase in imports of intermediate goods from Western Europe increases exports of final goods by 1.26 percent while the effect of EU accession decreases considerably (from 188 to 116 percent and 229 to 138; old versus new members) with the inclusion of this variable. Summarizing, controlling for multilateral resistance in the most recently recommended way indicates that there is a considerably larger EU effect for both exports of final products and for imports of intermediates and

\footnotetext{
${ }^{6}$ A Hausman test indicates that the random effects approach leads to inconsistent estimators.
} 
that the effect of production networks is sizable. However this effect may partly account for the increase in product diversification (extensive margin of trade).

Table 3 presents the results from estimating Equations 8 and $10^{7}$ that account for selection bias and firm heterogeneity (see Helpman et al., 2008). In each case we first estimated a probit model for each single year with traditional gravity variables (Equations 7 and 9$)^{8}$. From these estimates we obtained the linear prediction terms down-weighted by their standard errors (zhat, where $\mathrm{z}=\mathrm{x}, \mathrm{m}$ ) and the inverse Mills ratio (imills). These two elements are incorporated as regressors in the second-step estimations (Equations 8 and 10). The results from the second step estimations considering selection effects and firm heterogeneity are given in columns 1-3 of Table 3. Column (1) shows the estimates for imports of parts and components and columns 2 and 3 for final goods. All second stage models include country dummies that vary every 3 years and are estimated using the within transformation with exporter-importer-industry fixed effects

The coefficients on Zhat variables are statistically significant at the 1-percent level indicating that firm heterogeneity plays a role. The coefficient on the inverse Mills ratio (IMR) is also statistically significant and negatively signed showing evidence of selection effects. The estimates shown in the last column of Table 3 indicate that the increase in exports of final goods is partly explained by an increase in the intensive margin of imports (0.218).

Table 3: Determinants of Imports of Intermediates and Exports of Final Goods with Heckman Sample Selection and Firm Heterogeneity

\footnotetext{
${ }^{7}$ Results for the first step estimation (Equations 7 and 9) are available upon request from the authors.

${ }^{8}$ We estimate probit models for each year in the sample and store the zhat and inverse Mills ratio to use them in the second step estimation.
} 
With respect to the EU effects, the results in Table 3 indicate that there is a positive effect on both imports of intermediates and exports of final goods for both old and new members that is now slightly higher for imports of intermediates (those imports increase by about 127 percent with accession for old EU members and 141.5 for new members according to the results in column 1) and lower than before for exports of final goods (those exports increase by about 87 and 114 percent (for old and new EU members, respectively) with accession, according to last column results). A possible explanation of the discrepancy with respect to results in Table 2 is that the Helpman et al. (2008) method distinguishes between trade margins and accounts for the effect of the extensive margin (trade diversification) whereas the Baldwin and Taglioni (2006) method does not consider the effect of the extensive margin on total trade.

As a first robustness check, we have estimated similar models at a higher disaggregation level, namely 5 digits SITC classification. The results show in general higher integration effects for final goods and similar effects for intermediate goods ${ }^{9}$.

As a second robustness exercise, we have estimated time-varying integration effects for intermediate and final goods. The results obtained from equations (6) and (7) show that the EU-effect for intermediated goods is due to higher imports of intermediate goods in the years 2004-2006, whereas the positive EU-effect on exports of final goods materialized in higher exports during the years $2007-2009^{10}$.

In comparison with the results obtained previously in the literature, it is worth noting that we obtained higher EU-effects than Hornok (2010). This discrepancy is probably due to

\footnotetext{
${ }^{9}$ Results are available on request from the authors.

${ }^{10}$ Results are reported in the Appendix (Table A.4).
} 
the fact that we used more disaggregated data (5 digits versus 2 digits) and two additional years (2008-2009) and an additional integration episode.

\section{Conclusions}

This paper uses recently developed methodologies to estimate the effects of recent accessions to the EU on trade in final good and trade in part and components. In particular, it considers the inclusion of multilateral resistance factors as well as bilateral unobservable heterogeneity and incorporates firm heterogeneity into the estimation of the gravity model. It also controls for the existence of selection biases that arise when firms select into exporting, as only those firms with a high productivity are able to cover the additional fixed costs of exporting.

Our results indicate the 2004 and 2007 accessions of CEECs countries to the EU have increased trade in parts and components and also in final goods. As predicted by trade theories, a reduction in the trade cost (associated with the integration process) has possibly favored the segmentation of production processes and led to a better exploitation of comparative advantages and location. Additionally, integration into the EU has surely stimulated not only the exploitation of comparative advantages but also the production of new goods that were previously not produced. Finally, due to just in time production process, geographic proximity and sea access are also important determinants of trade in intermediate goods and their absence deters trade to a higher extent than in the case of final goods. 


\section{References}

Antimiani, A. and Costantini, V. (2013). 'Trade performances and technology in the enlarged European Union', Journal of Economic Studies, Vol. 40, No3, pp. 355 - 389.

Anderson, J.E. and Van Wincoop, E. (2003). 'Gravity with gravitas: a solution to the border puzzle’, American Economic Review, Vol. 93, pp. 170-192.

Anderson, J.E. (1979). 'A theoretical foundation for the gravity equation', American Economic Review, Vol. 69, pp. 106-116.

Athukorala, P. and Yamashita, N. (2006). 'Production fragmentation and trade integration: East Asia in a global context', North American Journal of Economics and Finance, Vol. 17, pp. 233-256.

Athukorala, P. (2006). 'Product fragmentation and trade patterns in East Asia', Asian Economic Papers, Vol. 4, No. 3, pp. 1-27.

Baier, S. L. and Bergstrand, J. H. (2007). 'Do free trade agreements actually increase members' international trade’, Journal of International Economics, Vol. 71, pp. 72-95.

Baldone, S., Sdogati, F. and Tajoli, L. (2001). 'Patterns and determinants of international fragmentation of production: evidence from outward processing trade between the EU and Central Eastern European countries', Review of World Economics, Vol. 137, No. 1, pp. 80-104.

Baldwin, R. and Taglioni, D. (2006). 'Gravity for dummies and dummies for gravity equations', National Bureau of Economic Research Working Paper 12516, Cambridge.

Baldwin, R. and Taglioni (2011). 'Gravity chains: Estimating bilateral trade flows when parts and components trade is important', National Bureau of Economic Research Working Paper 16672.

Bergstrand, J.H. (1985). 'The gravity equation in international trade: some microeconomic foundations and empirical evidence', The Review of Economics and Statistics, Vol. 67, pp. 474-481.

Bergstrand, J. H. and Egger, P. (2008). 'The growth of FDI relative to trade:

Measurement, determinants and consequences of international trade flows in intermediates', University of Notre Dame, mimeo.

Egger, H. and Egger, P. (2005). 'The determinants of EU processing trade', World Economy, Vol. 28, No. 2, pp. 147-168.

Hayakawa, K. and Yamashita, N. (2011). 'The role of Preferential Trade Agreements (PTAs) in facilitating global production networks’ IED Discussion Paper 280.2011.2.

Helpman, E., Melitz, M. and Rubinstein, Y. (2008). 'Estimating trade flows: trading partners and trading volumes’, The Quarterly Journal of Economics, Vol. 123, No. 2, pp. 441-487.

Hornok, C. (2010). 'Trade-enhancing EU enlargement and the resurgence of East-East trade' Focus on European Economic Integration Q3/10, pp. 79-94.

Hummels, D., Ishii, J. and Yi, K-M. (2001). 'The nature and growth of vertical specialization in world trade', Journal of International Economics, Vol. 54, No. 1, pp. 75-96. 
Kaminski, B. and Ng, F. (2005), 'Production disintegration and integration of Central Europe into global markets', International Review of Economics and Finance, Vol. 14, No. 3, pp. 377-390.

Kimura, F., Takahashi, Y. and Hayakawa, K. (2007). 'Fragmentation and parts and components trade: comparison between East Asia and Europe', North American Journal of Economics and Finance, Vol. 18, pp. 23-40.

Melitz, M.J. (2003). 'The impact of trade on intra-industry reallocations and aggregate industry productivity’, Econometrica, Vol. 71, No. 6, pp. 1695-1925.

Navaretti, G. B., Haaland, J.I. and Venables, A. (2002). 'Multinational corporations and global production networks: the implications for trade policy”, Report prepared for the European Commission Directorate General for Trade, London: CEPR.

Ng, F. and Yeats, A.J. (2001). 'Production sharing in East Asia: who does what for whom, and why?' in Cheng, L.K. and Kierzkowski, H. (eds) Global production and trade in East Asia (pp. 63-109) (Boston: Kluwer Academic Publishers).

Ng, F. and Yeats, A.J. (2003). 'Major trade trends in East Asia: what are their implications for regional cooperation and growth?', Policy Research Working Paper 3084, Washington DC: World Bank.

Yeats, A.J. (2001). 'How big is global production sharing?', in Arndt, S.W. and Kierzkowski, H. (eds) Fragmentation: new production patterns in the world economy (Oxford: Oxford University Press).Yi, K (2003), 'Can Vertical Specialization Explain the Growth of World Trade?' Journal of Political Economy, Vol. 111, No 1, pp. 52-102.

Zeddies, G. (2011). 'Determinants of international fragmentation of production in the European Union’, Empirica, Vol. 38, No 4, pp. 511-537. 
TABLES

Table 1. Summary statistics

\begin{tabular}{|c|c|c|c|c|c|}
\hline Variable & Obs & Mean & Std. Dev & $\underline{\text { Min }}$ & $\underline{\text { Max }}$ \\
\hline XF & 112530 & 5127050 & $4.20 \mathrm{E}+07$ & 0 & $2.40 \mathrm{E}+09$ \\
\hline MP & 94116 & 5364679 & $4.21 \mathrm{E}+07$ & 0 & $2.32 \mathrm{E}+09$ \\
\hline LXF & 63997 & 12.094 & 3.338 & 0 & 21.599 \\
\hline $\mathbf{L M}$ & 75707 & 12.029 & 3.290 & 0 & 21.566 \\
\hline LYi & 112530 & 11.094 & 0.840 & 9.406 & 12.801 \\
\hline $\mathbf{L Y j}$ & 111210 & 12.625 & 1.540 & 9.011 & 16.257 \\
\hline LYHi & 112530 & 1.666 & 0.578 & 0.391 & 2.652 \\
\hline LYHj & 111210 & 2.992 & 0.786 & 0.391 & 4.389 \\
\hline $\mathbf{E U}$ & 112530 & 0.217 & 0.442 & 0 & 1 \\
\hline CEEs & 112530 & 0.041 & 0.368 & 0 & 1 \\
\hline LD & 112530 & 7.481 & 1.119 & 4.088 & 9.821 \\
\hline LAND & 112530 & 0.677 & 0.382 & 0 & 2 \\
\hline CONTIG & 112530 & 0.102 & 0.303 & 0 & 1 \\
\hline
\end{tabular}

Note: XF denotes exports of final goods in current $€$ and MP denotes imports of parts and componets. (L) denotes natural logs. LYi and LYj are importers' and exporters’ GDPs, respectively; LYHi and LYHj are importers' and exporters' GDPs per capita, respectively; ld is geographical distance and, LANDi, LANDj and CONTIG are dummies that equal to 1 when countries $\mathrm{i}$ or $\mathrm{j}$ are landlocked or share a border, respectively. 
Table 2. Determinants of Imports of Intermediate goods and Exports of Final Goods by the CEECs - Linear Models

\begin{tabular}{|c|c|c|c|c|c|c|}
\hline VARIABLES & $\begin{array}{l}(1) \\
\text { Parts } \\
\text { tk FE }\end{array}$ & $\begin{array}{l}(2) \\
\text { Final } \\
\text { tk FE }\end{array}$ & $\begin{array}{c}(3) \\
\text { Final-Parts tk } \\
\text { FE }\end{array}$ & $\begin{array}{c}(4) \\
\text { Parts } \\
\text { MRT ijk FE }\end{array}$ & $\begin{array}{c}(5) \\
\text { Final } \\
\text { MRT ijk FE }\end{array}$ & $\begin{array}{c}(6) \\
\text { Final-Parts } \\
\text { MRT ijk FE }\end{array}$ \\
\hline EU & $\begin{array}{l}0.389 * * * \\
{[0.0457]}\end{array}$ & $\begin{array}{c}0.493 * * * \\
{[0.0498]}\end{array}$ & $\begin{array}{l}0.279 * * * \\
{[0.0536]}\end{array}$ & $\begin{array}{l}0.800 * * * \\
{[0.0222]}\end{array}$ & $\begin{array}{l}1.060 * * * \\
{[0.0318]}\end{array}$ & $\begin{array}{c}0.771 * * * \\
{[0.0342]}\end{array}$ \\
\hline CEES & $\begin{array}{l}0.949 * * * \\
{[0.0815]}\end{array}$ & $\begin{array}{l}0.911 * * * \\
{[0.0784]}\end{array}$ & $\begin{array}{c}0.672^{* * *} \\
{[0.0881]}\end{array}$ & $\begin{array}{l}0.857 * * * \\
{[0.0547]}\end{array}$ & $\begin{array}{l}1.191 * * * \\
{[0.0506]}\end{array}$ & $\begin{array}{l}0.868 * * * \\
{[0.0521]}\end{array}$ \\
\hline LABSYD & $\begin{array}{l}-0.00907 \\
{[0.0315]}\end{array}$ & $\begin{array}{c}-0.0348 \\
{[0.0321]}\end{array}$ & $\begin{array}{c}-0.0980 * * * \\
{[0.0359]}\end{array}$ & $\begin{array}{l}0.302 * * * \\
{[0.0314]}\end{array}$ & $\begin{array}{l}0.253 * * * \\
{[0.0353]}\end{array}$ & $\begin{array}{c}0.0578 \\
{[0.0386]}\end{array}$ \\
\hline $\mathbf{L M}(\mathrm{t}-1)$ & & & $\begin{array}{c}0.143^{* * *} \\
{[0.0109]}\end{array}$ & & & $\begin{array}{l}0.126 * * * \\
{[0.00943]}\end{array}$ \\
\hline LYI & $\begin{array}{l}1.239 * * * \\
{[0.0874]}\end{array}$ & $\begin{array}{c}0.445 * * * \\
{[0.121]}\end{array}$ & $\begin{array}{c}0.265^{*} \\
{[0.139]}\end{array}$ & & & \\
\hline LYJ & $\begin{array}{l}0.570 * * * \\
{[0.0893]}\end{array}$ & $\begin{array}{c}0.468 * * * \\
{[0.101]}\end{array}$ & $\begin{array}{c}0.404 * * * \\
{[0.118]}\end{array}$ & & & \\
\hline LD & $\begin{array}{c}-1.569 * * * \\
{[0.0258]}\end{array}$ & $\begin{array}{c}-1.182^{* * *} \\
{[0.0305]}\end{array}$ & $\begin{array}{c}-1.081^{* * *} \\
{[0.0401]}\end{array}$ & & & \\
\hline LAND & $\begin{array}{c}0.224 * * * \\
{[0.0344]}\end{array}$ & $\begin{array}{c}0.512 * * * \\
{[0.0393]}\end{array}$ & $\begin{array}{l}0.420 * * * \\
{[0.0420]}\end{array}$ & & & \\
\hline CONTIG & $\begin{array}{l}0.467 * * * \\
{[0.0723]}\end{array}$ & $\begin{array}{l}0.442 * * * \\
{[0.0763]}\end{array}$ & $\begin{array}{l}0.388 * * * \\
{[0.0816]}\end{array}$ & & & \\
\hline AVLYI & $\begin{array}{c}-0.374 * * * \\
{[0.0912]}\end{array}$ & $\begin{array}{c}0.645^{* * * *} \\
{[0.123]}\end{array}$ & $\begin{array}{c}0.686 * * * \\
{[0.140]}\end{array}$ & & & \\
\hline AVLYJ & $\begin{array}{c}0.800 * * * \\
{[0.0906]}\end{array}$ & $\begin{array}{c}0.374 * * * \\
{[0.102]}\end{array}$ & $\begin{array}{c}0.335 * * * \\
{[0.118]}\end{array}$ & & & \\
\hline AVLABSYD & $\begin{array}{c}0.0688 * \\
{[0.0398]}\end{array}$ & $\begin{array}{c}-0.108^{* * * *} \\
{[0.0412]}\end{array}$ & $\begin{array}{l}-0.110^{* *} \\
{[0.0461]}\end{array}$ & & & \\
\hline CONSTANT & $\begin{array}{c}-5.997 * * * \\
{[0.474]}\end{array}$ & $\begin{array}{c}-4.203 * * * \\
{[0.522]}\end{array}$ & $\begin{array}{c}-4.498 * * * \\
{[0.598]}\end{array}$ & $\begin{array}{c}10.82 * * * \\
{[0.175]}\end{array}$ & $\begin{array}{c}11.05^{* * *} \\
{[0.195]}\end{array}$ & $\begin{array}{c}9.807 * * * \\
{[0.270]}\end{array}$ \\
\hline OBSERVATIONS & 75,076 & 63,436 & 41,963 & 75,113 & 63,461 & 41,978 \\
\hline R-SQUARED & 0.575 & 0.485 & 0.513 & 0.068 & 0.076 & 0.069 \\
\hline NUMBER OF ID & & & & 8,051 & 7,622 & 5,682 \\
\hline
\end{tabular}

Note: The dependent variable is bilateral imports of intermediates and bilateral exports of final goods measured at current prices; LYi and LYj are importers' and exporters' GDPs, respectively; LABSYD denotes the log of the absolute value difference in income per capita between countries I and j; LD is distance; LM are imports of intermediates; LAND, CONTIG, EU and CEEs are dummies equal to 1 when countries are landlocked, share a border, or belong to the old-EU or to the new-EU group of CEECs, respectively; robust standard errors clustered by sector-exporter-and-importer. ${ }^{*} \mathrm{p}<0.10,{ }^{* *} \mathrm{p}<0.05,{ }^{* * *}$ $\mathrm{p}<0.01$. 
Table 3. Determinants of Imports of Intermediates and Exports of Final Goods with Heckman Sample Selection and Firm Heterogeneity $\left(2^{\text {nd }}\right.$ step results)

\begin{tabular}{lccc}
\hline HMR & $(1)$ & $(2)$ & $(3)$ \\
VARIABLES & Parts & Final & Final-parts \\
& MRT ijk FE & MRT ijk FE & MRT ijk FE \\
\hline \multirow{2}{*}{ EU } & & & \\
& $0.819^{* * *}$ & $0.921^{* * *}$ & $0.626^{* * *}$ \\
CEES & {$[0.0232]$} & {$[0.0303]$} & {$[0.0355]$} \\
& $0.882^{* * *}$ & $1.036^{* * *}$ & $0.763^{* * *}$ \\
LABSYD & {$[0.0561]$} & {$[0.0490]$} & {$[0.0552]$} \\
& $0.184^{* * *}$ & 0.00917 & $-0.123^{* * *}$ \\
IMR & {$[0.0341]$} & {$[0.0333]$} & {$[0.0360]$} \\
& $-1.870^{* * *}$ & $-3.672^{* * *}$ & $-3.070^{* * *}$ \\
Zhat1 & {$[0.216]$} & {$[0.156]$} & {$[0.176]$} \\
& $-0.0741^{* * *}$ & $-0.0262^{* *}$ & -0.0106 \\
Zhat2 & {$[0.0203]$} & {$[0.0112]$} & {$[0.0121]$} \\
& $0.00677^{* * *}$ & $0.00722^{* * *}$ & $0.00631^{* * *}$ \\
Zhat3 & {$[0.00123]$} & {$[0.000775]$} & {$[0.000861]$} \\
& $-0.000142^{* * *}$ & $-0.000162^{* * *}$ & $-0.000152^{* * *}$ \\
LMhat(t-1) & {$[3.06 \mathrm{e}-05]$} & {$[2.08 \mathrm{e}-05]$} & {$[2.31 \mathrm{e}-05]$} \\
& & & $0.218^{* * *}$ \\
CONSTANT & & & {$[0.0350]$} \\
& $11.57^{* * *}$ & $12.43^{* * *}$ & $9.617^{* * *}$ \\
OBSERVATIONS & {$[0.265]$} & {$[0.210]$} & {$[0.455]$} \\
R-SQUARED & 73,082 & 63,436 & 46,408 \\
NUMBER OF ID & 0.073 & 0.125 & 0.098 \\
N & 7,865 & 7,622 & 6,089 \\
\hline
\end{tabular}

Note: The dependent variables are the bilateral imports of intermediates and the bilateral exports of final goods measured at current prices; Zhat1 denotes linear predictors of imports and exports down-weighted by their standard errors, Zhat2 and Zhat3 are the squared and cube of Zhat1 and IMR is the inverse Mills ratio. Robust standard errors clustered by industry-exporter-and-importer are reported below each coefficient.* $\mathrm{p}<0.10, * * \mathrm{p}<0.05, * * * \mathrm{p}<0.01$. 


\section{Appendix}

Table A.1. Economic Organizations of countries in the dataset

\begin{tabular}{|c|c|c|}
\hline Abbreviation & Title & Members \\
\hline$E U$ & European Union & $\begin{array}{l}\text { Admitted before 1999: Austria, Belgium, Denmark, Finland, } \\
\text { France, Germany, Greece, Ireland, Italy, Luxembourg, } \\
\text { Netherlands, Portugal, Spain, Sweden, United Kingdom, } \\
\text { Admitted in 2004: Czech Republic, Hungary, Poland, } \\
\text { Slovak Republic } \\
\text { Admitted in 2007: Bulgaria, Romania }\end{array}$ \\
\hline OECD & $\begin{array}{l}\text { Organization for } \\
\text { Economic Co-operation } \\
\text { and Development }\end{array}$ & $\begin{array}{l}\text { Admitted before 1999: Austria, Australia, Belgium, Canada, } \\
\text { Czech Republic, Denmark, Finland, France, Germany, } \\
\text { Greece, Hungary, Iceland, Ireland, Italy, Japan, } \\
\text { Luxembourg, Mexico, Netherlands, New Zealand, Norway, } \\
\text { Poland, Portugal, South Korea, Spain, Sweden, Switzerland, } \\
\text { Turkey, United Kingdom, United States } \\
\text { Admitted in 2000: Slovakia }\end{array}$ \\
\hline CEECs & $\begin{array}{l}\text { Central Eastern } \\
\text { European Countries }\end{array}$ & $\begin{array}{l}\text { Bulgaria, Czech Republic, Hungary, Poland, Romania, } \\
\text { Slovakia }\end{array}$ \\
\hline
\end{tabular}


Table A.2. List of Parts and Components according to the Standard Industrial

\section{Classification (SITC) System Revision 3}

\begin{tabular}{|c|c|c|}
\hline Division & Codes for Parts and Components & $\begin{array}{l}\text { No } \\
\text { codes }\end{array}$ \\
\hline $\begin{array}{l}\text { Power-generating machinery } \\
\text { and equipment (SITC 71) }\end{array}$ & $\begin{array}{l}\text { 71191, 71192, 71280, 71311, 71319, 71321, 71322, 71323, 71332, } \\
\text { 71333, 71391, 71392, 71441, 71449, 71481, 71489, 71491, 71499, } \\
\text { 71690, 71819, 71878, 71899 }\end{array}$ & 22 \\
\hline $\begin{array}{l}\text { Machinery specialized for } \\
\text { particular industries (SITC } \\
\text { 72) }\end{array}$ & $\begin{array}{l}\text { 72119, 72129, 72139, 72198, 72199, 72391, 72392, 72393, 72399, } \\
\text { 72439, 72449, 72461, 72467, 72468, 72488, 72491, 72492, 72591, } \\
\text { 72599, 72635, 72689, 72691, 72699, 72719, 72729, 72819, 72829, } \\
\text { 72839, 72851, 72852, 72853, 72855 }\end{array}$ & 32 \\
\hline $\begin{array}{l}\text { Metalworking machinery } \\
\text { (SITC 73) }\end{array}$ & 73511, 73513, 73515, 73591, 73595, 73719, 73729, 73739, 73749 & 9 \\
\hline $\begin{array}{l}\text { General industrial } \\
\text { machinery and equipment, } \\
\text { n.e.s., and machine parts, } \\
\text { n.e.s (SITC 74) }\end{array}$ & $\begin{array}{l}\text { 74128, 74135, 74139, 74149, 74159, 74172, 74190, 74291, 74295, } \\
\text { 74380, 74391, 74395, 74419, 74491, 74492, 74493, 74494, 74519, } \\
\text { 74529, 74539, 74568, 74593, 74597, 74610, 74620, 74630, 74640, } \\
\text { 74650, 74680, 74691, 74699, 74710, 74720, 74730, 74740, 74780, } \\
\text { 74790, 74810, 74821, 74822, 74839, 74840, 74850, 74860, 74890, } \\
\text { 74991, 74999 }\end{array}$ & 48 \\
\hline $\begin{array}{l}\text { Office machines and } \\
\text { automatic data processing } \\
\text { machines } \\
\text { (SITC 75) }\end{array}$ & 75910, 75980, 75990, 75991, 75993, 75995, 75997 & 7 \\
\hline $\begin{array}{l}\text { Telecommunications and } \\
\text { sound recording and } \\
\text { reproducing apparatus and } \\
\text { equipment } \\
\text { (SITC 76) }\end{array}$ & 76211, 76312, 76491, 76492, 76493, 76499 & 6 \\
\hline $\begin{array}{l}\text { Electrical machinery, } \\
\text { apparatus and appliances, } \\
\text { n.e.s., and electrical parts } \\
\text { thereof (SITC 77) }\end{array}$ & $\begin{array}{l}\text { 77129, 77220, 77231, 77232, 77233, 77235, 77238, 77241, 77242, } \\
\text { 77243, 77244, 77245, 77249, 77251, 77252, 77253, 77254, 77255, } \\
\text { 77257, 77258, 77259, 77261, 77262, 77281, 77282, 77311, 77312, } \\
\text { 77313, 77314, 77315, 77316, 77317, 77318, 77322, 77323, 77324, } \\
\text { 77326, 77328, 77329, 77423, 77429, 77549, 77557, 77579, 77589, } \\
\text { 77611, 77612, 77621, 77623, 77625, 77627, 77629, 77631, 77632, } \\
\text { 77633, 77635, 77637, 77639, 77641, 77642, 77643, 77644, 77645, } \\
\text { 776446, 77649, 77681, 77688, 77689, 77812, 77817, 77819, } \\
\text { 77822, 77823, 77824, 77829, 77831, 77833, 77834, 77835, 77848, } \\
\text { 77869, 77879, 77883, 77885, 77886, 77889 }\end{array}$ & 86 \\
\hline Road vehicles (SITC 78) & $\begin{array}{l}\text { 78421, 78425, 78431, 78432, 78433, 78434, 78435, 78436, 78439, } \\
\text { 78535, 78536, 78537, 78689 }\end{array}$ & 13 \\
\hline $\begin{array}{l}\text { Other transport equipment } \\
\text { (SITC 79) }\end{array}$ & 79199, 79291, 79293, 79295, 79297 & 5 \\
\hline $\begin{array}{l}\text { Furniture and parts thereof } \\
\text { (SITC 82) }\end{array}$ & $82111,82112,82119,82180$ & 4 \\
\hline $\begin{array}{l}\text { Measuring, checking, } \\
\text { analyzing and controlling } \\
\text { instruments and apparatus, } \\
\text { n.e.s. (SITC 874) }\end{array}$ & $\begin{array}{l}\text { 87412, 87414, 87424, 87426, 87439, 87449, 87454, 87456, 87469, } \\
87479,87490\end{array}$ & 11 \\
\hline $\begin{array}{l}\text { Photographic apparatus, } \\
\text { equipment and supplies and } \\
\text { optical goods, n.e.s; watches } \\
\text { and clocks (SITC 88) }\end{array}$ & $\begin{array}{l}\text { 88112, 88113, 88114, 88115, 88123, 88124, 88134, 88136, 88210, } \\
\text { 88220, 88230, 88240, 88250, 88260, 88310, 88390, 88415, 88417, } \\
88419,88421,88422,88431,88432,88433,88439,88551,88552, \\
88571,88591,88596,88597,88598,88599\end{array}$ & 17 \\
\hline
\end{tabular}


Table A.3. Definitions of variables

\begin{tabular}{|c|c|}
\hline Variable & Definition \\
\hline Reporter & CEECs countries \\
\hline Partner & EU and OECD countries \\
\hline $\mathrm{Y}_{\mathrm{i}}$ & GDP of reporter country i. \\
\hline$Y_{j}$ & GDP of partner country $\mathrm{j}$. \\
\hline $\mathrm{YH}_{\mathrm{i}}$ & GDP per capita of reporter country i. \\
\hline $\mathrm{YH}_{\mathrm{j}}$ & GDP per capita of partner country j. \\
\hline ABSYD $_{i j}$ & Absolute value difference between GDP per capita of reporter and partner country. \\
\hline $\mathrm{D}_{\mathrm{ij}}$ & $\begin{array}{l}\text { Geographical distance expressed in kilometers between reporter's i and partner's j capital } \\
\text { cities. }\end{array}$ \\
\hline LAND & $\begin{array}{l}\text { Binary variable that takes the value of " } 1 \text { " if the reporter or the partner country is } \\
\text { landlocked, the value of " } 2 \text { " when both are landlocked, and " } 0 \text { " otherwise. }\end{array}$ \\
\hline CONTIG $_{\mathrm{ij}}$ & $\begin{array}{l}\text { Binary variable that takes the value " } 1 \text { " if the reporter country "i" and partner country " } \mathrm{j} \text { " } \\
\text { share a common border. }\end{array}$ \\
\hline CEEs & $\begin{array}{l}\text { Binary variable that takes the value " } 1 \text { " if reporter and partner countries belong to CEECs } \\
\text { and to the EU and " } 0 \text { " otherwise. }\end{array}$ \\
\hline$\overline{\mathrm{EU}_{\mathrm{ij}}}$ & $\begin{array}{l}\text { Binary variable that takes the value " } 1 \text { " if both countries are members of EU for old EU } \\
\text { members. }\end{array}$ \\
\hline
\end{tabular}


Table A.4: Determinants of Imports of Intermediates and Exports of Final Goods with Well-Specified Multilateral Resistance Terms - Linear Models

\begin{tabular}{|c|c|c|c|c|c|c|}
\hline \multicolumn{7}{|c|}{ With $x-m, x-t$ and $m-t$ fixed effects and time-varying $E U$ effects } \\
\hline \multirow[b]{2}{*}{ Linear regression } & \multicolumn{2}{|l|}{ Parts } & \multicolumn{2}{|l|}{ Finals } & \multicolumn{2}{|l|}{ Finals } \\
\hline & $\underline{\mathbf{b}}$ & $\underline{\mathbf{s e}}$ & $\underline{\mathbf{b}}$ & $\underline{\mathbf{s e}}$ & $\underline{\mathbf{b}}$ & $\underline{\mathbf{s e}}$ \\
\hline EU_2004 & $0.322 * * *$ & 0.113 & -0.090 & 0.167 & -0.013 & 0.190 \\
\hline EU_2005 & $0.577 * * *$ & 0.114 & -0.169 & 0.157 & -0.259 & 0.175 \\
\hline EU_2006 & $0.409 * * *$ & 0.113 & -0.322 & 0.155 & -0.433 & 0.177 \\
\hline EU_2007 & -0.601 & 0.236 & $2.164 * * *$ & 0.353 & $2.128 * *$ & 0.393 \\
\hline EU_2008 & -0.482 & 0.234 & $2.566^{* * *}$ & 0.351 & $2.656^{* * *}$ & 0.392 \\
\hline EU_2009 & -0.781 & 0.237 & $2.265 * * *$ & 0.349 & $2.391 * * *$ & 0.385 \\
\hline average_EU & 0.436 & & 1.069 & & 1.078 & \\
\hline LM (T-1) & & & & & $0.108^{* * *}$ & \\
\hline NOBS & 75076 & & 63997 & & 42277 & \\
\hline R-SQUARED & 0.656 & & 0.5313 & & 0.5707 & \\
\hline ROOT MSE & 1.9373 & 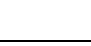 & 2.296 & 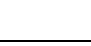 & 2.1165 & 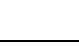 \\
\hline
\end{tabular}

